\title{
Exotic molluscs in State of Paraíba, Northeast Brazil: a bibliographic survey
}

\section{Ronilson José da Paz ${ }^{1}$, Luciano de Brito Júnior ${ }^{2}$ and Marilia Carolina Pereira da $\mathrm{Paz}^{3}$}

${ }^{1}$ Instituto Brasileiro do Meio Ambiente e dos Recursos Naturais Renováveis (IBAMA), Caixa Postal 5063, CEP 58051-900, João Pessoa, PB, Brazil. E-mail: ronilson.paz@gmail.com.

2Universidade Federal de Campina Grande (UFCG), Unidade Acadêmica de Ciências Biológicas. Rodovia Patos-Teixeira, Jatobá, CEP 58700-970, Patos, PB, Brazil. E-mail: lbritojunior@gmail.com.

${ }^{3}$ Universidade Federal da Paraíba (UFPB), Centro de Ciências Exatas e da Natureza, Curso de Licenciatura em Ciências Biológicas, CEP 58051-900, João Pessoa, PB, Brazil.

\begin{abstract}
The control of alien species is the main challenge for the maintenance the integrity of biodiversity. We present a list of exotic mollusc species recorded in the literature from State of Paraíba (PB), Northeast Brazil, as of April 2014. The total number of species of exotic mollusc recorded is seven, two Bivalvia and five Gastropoda. The Class Bivalvia's species was represented by Isognomon bicolor (Adams, 1845) and Corbicula fluminea (Müller, 1774), and Class Gastropoda's species by Achatina fulica (Bowdich, 1822), Melanoides tuberculata (Müller, 1774), Physella acuta (Draparnaud, 1805), Aplexa marmorata (Guilding, 1828) and Lymnaea columella (Say, 1817).
\end{abstract}

Keywords: Alien species, exotic and invasive fauna, Mollusca.
Received

April 22, 2014

Accepted May 18, 2014

Released June 30, 2014

Open Acess Full Text Article

\section{Introduction}

As well known and widely accepted, exotic species, also called nonindigenous, or invasive species, are species that have moved beyond their natural geographical range of habitat.

The impacts of introducing exotic species can be divided into two areas: ecological, and economic. These categories, however, are inter-dependent; an exotic species which has an ecological impact also has an economic one, and vice versa. Then, the control of the alien species is the main challenge for the maintenance the integrity of biodiversity.

This paper may be viewed as a sequel to Paz et al. (2013) in which we listed the invasive exotic fauna of the State of Paraíba.
The presence of a total of seven (7) exotic introduced mollusks species was confirmed to State of Paraíba (PB), a small state within the Northeast Brazil region, as of April 2014.

\section{Materials and Methods}

For inclusion in this list, it was considered exotic invasive species of Mollusca that was introduced or settled in an ecosystem or natural or semi-natural habitat, and that is an agent of change or threat to wild biodiversity, either by their behavior attacker, or at risk of genetic contamination. 
After defining the criteria for obtaining the sample, surveys were made to the following sources: Internet;

- Electronic databases shared on the shared;

- Local electronic data banks, not publications.

- Regular electronic and print

Various electronic sources that could provide information on exotic species were also consulted:

- www.periodicos.capes.gov.br

- www.portaldapesquisa.com.br

- lattes.cnpq.br

- www.isiknowledge.com

- www.sciencedirect.com

Other tools online search engine (like Google) were also used, primarily for access to pages laboratories, researchers and projects related to invasive alien species, using the following terms:

- Espécies exóticas AND Mollusca AND Paraíba (in Portuguese)

- Água de lastro AND Mollusca AND Paraíba (in Portuguese)

- Ballast water AND Mollusca

AND Paraíba

- Exotic species AND Mollusca

AND Paraíba

-Allien species AND Mollusca

AND Paraíba

- Invasive species AND Mollusca

AND Paraíba

- Introduced species AND Mollusca

AND Paraíba

- Nova ocorrência AND Mollusca

AND Paraíba

- Primeiro registro AND Mollusca

AND Paraíba

- First record AND Mollusca AND

taxon AND Paraíba

- New record AND Mollusca AND

taxon AND Paraíba

\section{Results}

We have seven exotic molluscs species recorded in the literature from State of Paraíba (PB), Brazil, as of April 2014, three Bivalvia and five Gastropoda.

\section{Classe BIVALVIA}

Family Pteriidae Gray, 1847

Genus Isognomon Solander, 1786

Isognomon bicolor (Adams, 1845)

Baía da Traição Municipality; Cabedelo Municipality: Pier de

Cabedelo; Conde Municipality: Jacarapé beach, Maceiozinho beach, Jacumã; Tabatinga beach, Coqueirinho beach, Carapibus beach, Tambaba beach; João Pessoa Municipality: Cabo Branco beach; Mataraca Municipality: Barra de Camaratuba; Pitimbu Municipality: Pedras de Galé; Rio Tinto Municipality: Mamanguape river estuary (Dias et al., 2013).

Family Corbiculidae Gray, 1847

Genus Corbicula Megerle von Mühlfeld, 1811

Corbicula fluminea (Müller, 1774)

State of Paraíba (Mansur et al. (2004); Triunfo Municipallity (Instituto Hórus, 2009).

\section{Class GASTROPODA}

Family Achatinidae Swainson, 1840

Genus Achatina Lamarck, 1799

Achatina fulica (Bowdich, 1822)

João Pessoa Municipallity; Cabedelo Municipallity (Paz and Rego, 2006). Considered as one of 100 of the world's worst invasive alien species, by The Invasive Species Specialist Group (ISSG), a specialist group of the Species Survival Commission (SSC) of the World Conservation Union (IUCN).

Family Thiaridae Gill, 1871

Genus Melanoides Olivier, 1804

Melanoides tuberculata (Müller, 1774)

João Pessoa Municipallity: Solon de Lucena Park's lagoon; Campina Grande Municipallity: Bodocongó dam; Santa Luzia Municipallity: Santa Luzia dam; São Mamede Municipallity: São Mamede dam; Sousa Municipallity: São Gonçalo dam (Paz et al., 1995). Campina Grande Municipallity: Bodocongó dam (Abílio and Watanabe, 1998; Abílio et al., 2006); São João do 
Cariri Municipallity: Aveloz stream, Namorado dam; Taperoá Municipallity: Taperoá II dam (Abílio et al., 2007).

Family Physidae Fitzinger, 1833

Genus Physella Haldeman, 1842

Physella acuta (Draparnaud, 1805)

State of Paraíba (Leão et al., 2011; Paz et al., 2013).

Genus Aplexa Fleming, 1820

Aplexa marmorata (Guilding, 1828)

Campina Grande Municipallity:

Bodocongó dam (Abílio and

Watanabe, 1998); Taperoá

Municipallity: Panati lagoon (Abílio et al., 2007).

Family Lymnaeidae Rafinesque, 1815

Genus Lymnaea Lamarck, 1799

Lymnaea columella (Say, 1817)

Campina Grande Municipallity, Bodocongó dam (Abílio and Watanabe, 1998; Abílio et al., 2006).

\section{Discussion}

The globalization of economies and trade have facilitated the spread of exotic species (Karatayev et al., 2007), including the species listed in this study.

According Lowe et al. (2000), Achatina fulica (Bowdich, 1822) was considered as one of 100 of the world's worst invasive alien species, by The Invasive Species Specialist Group (ISSG), a specialist group of the Species Survival Commission (SSC) of the World Conservation Union (IUCN).

\section{References}

Abílio, F. J. P.; Fonseca-Gessner, A. A.; Leite, R. L.; Ruffo, T. L. M. Gastrópodes e outros invertebrados do sedimento e associados à macrófita Eichhornia crassipes de um açude hipertrófico do semi-árido paraibano. Revista de Biologia e Ciências da Terra, Suplemento Especial, p. 165-178, 2006.

Abílio, F. J. P.; Ruffo, T. L. M.; Souza, A. H. F. F. ; Florentino, H. S.; Oliveira Junior, E. T.; Meireles, B. N.; Santana, A. C. D. Macroinvertebrados bentônicos como bioindicadores de qualidade ambiental de corpos aquáticos da Caatinga. Oecol. Bras., v. 11, p. 397-409, 2007.
Abílio, F. J. P.; Watanabe, T. Ocorrência de Lymnaea columella (Gastropoda: Lymnaeidae), hospedeiro intermediário da Fasciola hepatica, para o Estado da Paraíba, Brasil. Rev. Saúde Pública, v. 32, p. 185-186, 1998.

Agudo-Padrón, A. I. Exotic mollusks (Mollusca, Gastropoda et Bivalvia) in Santa Catarina State, Southern Brazil region: check list and regional spatial distribution. Biodiversity Journal, v. 2, p. 53-58, 2011.

Dias, T. L. P.; Mota, E, L. S.; Gondim, A. I.; Oliveira, J. M.; Rabelo, E. F.; Almeida, S. M.; Christoffersen, M. L. Isognomon bicolor (C. B. Adams, 1845) (Mollusca: Bivalvia): first record of this invasive species for the States of Paraíba and Alagoas and new records for other localities of Northeastern Brazil. Check List, v. 9, p. 157161, 2013.

Instituto Hórus de Desenvolvimento e Conservação Ambiental/The Nature Conservancy. Base de Dados sobre Espécies Exóticas Invasoras em I3N-Brasil. 2009. Available from: <http://www.institutohorus. org.br>. Accessed in: Mar. 20, 2014.

Karatayev, A. Y.; Padilla, D. K.; Minchin, D.; Boltovskoy, D.; Burlakova, L. E. Changes in global economies and trade: the potential spread of exotic freshwater bivalves. Biol. Invasions, v. 9, p 161-180, 2007.

Leão, T. C. C.; Almeida, W. R.; Dechoum, M. S.; Ziller, S. R. Espécies exóticas invasoras no Nordeste do Brasil: contextualização, manejo e políticas públicas. Recife: CEPAN/ Instituto Hórus, 2011.

Lowe, S.; Browne, M.; Boudjelas, S.; De Poorter, M. 100 of the World's Worst Invasive Alien Species: a selection from the Global Invasive Species Database. Auckland: The Invasive Species Specialist Group (ISSG), Species Survival Commission (SSC), World Conservation Union (IUCN), 2000. 12 p.

Mansur, M. C. D.; Callil, C. T.; Cardoso, F. R.; Ibara, J. A. A. Uma retrospectiva e mapeamento da invasão de espécies de Corbicula (Mollusca, Bivalvia, Veneroida, Corbiculidae) oriundas do sudeste asiático, na América do Sul. In: Silva, J. S. V.; Souza, R. C. C. (Eds.). Água de lastro e bioinvasão. Rio de Janeiro: Interciência, 2004.

Paz, M. C. P.; Medeiros, P. C. R.; Silva, T. C. F.; Freitas, G. L.; Paz, R. J. Contribuição à lista da fauna exótica invasora do Estado da Paraíba, Brasil. Anais do Congresso Brasileiro de Gestão Ambiental e Sustentabilidade, v. 1, 231-236, 2013.

Paz, R. J.; Watanabe, T.; Dijck, M. P. M.; Abílio, F. J. P. First record of Melanoides tuberculata (Müller, 1779) (Gastropoda: 
Prosobranchia: Thiaridae) in State of Paraíba (Brazil) and its possible ecological implications. Rev. Nordestina Biol., v. 10, p. 79-84, 1995.

Paz, R. J.; Rego, R. D. P. A Educação Ambiental no controle do caracol gigante africano. In: Paz, R. J. (Org.). Fundamentos, reflexões e experiências em Educação
Ambiental. João Pessoa: Ed. Universitária/ UFPB, 2006. p. 207-217.

Vitousek, P. M.; D’Antonio, C. M.; Loope, L. L.; Rejmánek, M.; Westbrooks, R. Introduced species: a significant component of human-caused global change. New Zealand Journal of Ecology, v. 21, p. 1-16, 1997. 